\title{
Echokardiograficzna rozkurczowa próba wysiłkowa
}

\author{
Echocardiographic diastolic stress test
}

\author{
Ewa Szczerba ${ }^{1,2}$, Anna Fojt ${ }^{1}$, Michał Marchel ${ }^{1}$ \\ ${ }^{1}$ I Katedra i Klinika Kardiologii Warszawskiego Uniwersytetu Medycznego \\ ${ }^{2}$ Zakład Kardiologii Instytutu Matki i Dziecka w Warszawie
}

\section{Streszczenie}

Zaburzenia funkcji rozkurczowej lewej komory mogą tłumaczyć objawy niewydolności serca, jeśli prowadzą do podwyższonego ciśnienia w lewym przedsionku. Funkcja rozkurczowa dynamicznie się zmienia między innymi pod wpływem wysiłku fizycznego. Z tego powodu w spoczynkowym badaniu echokardiograficznym można nie stwierdzić zaburzeń funkcji rozkurczowej tłumaczącej objawy niewydolności serca. W artykule zaprezentowano metody oceny funkcji rozkurczowej w spoczynkowym badaniu echokardiograficznym, wskazania do echokardiograficznej rozkurczowej próby wysiłkowej, protokoły jej wykonania i sposób interpretacji wyników.

Słowa kluczowe: echokardiografia, rozkurcz, próba wysiłkowa, dysfunkcja rozkurczowa, niewydolność serca

Folia Cardiologica 2018; 13, 6: 588-594

\section{Wstęp}

Prawidłowa funkcja rozkurczowa miokardium stanowi podstawę efektywnej hemodynamicznie pracy serca. Między innymi od niej zależy wypełnienie lewej komory, a w konsekwencji - również objętość wyrzutowa lewej komory. Należy pamiętać, że funkcja rozkurczowa jest parametrem mogącym ulegać dynamicznym zmianom w czasie, między innymi w zależności od obciążenia wstępnego, obciążenia następczego, czynności serca. Zaburzenia funkcji rozkurczowej mogą być zarówno przemijające - mają wtedy charakter bardziej czynnościowy, tak jak w ostrym niedokrwieniu, jak i mogą być utrwalone, gdy wynikają z już dokonanej przebudowy mięśnia sercowego [1]. Zaburzenia mechanizmów warunkujących prawidłowy rozkurcz lewej komory skutkują wzrostem ciśnienia w jej wnętrzu i upośledzeniem prawidłowego napływu krwi z lewego przedsionka i z krążenia płucnego. Warto w tym miejscu wspomnieć, że jeśli nie istnieje istotna przeszkoda w drodze napływu krwi z lewego przedsionka do lewej komory (jak w przypadku istotnej stenozy mitralnej czy śluzaka lewego przedsionka wpuklającego się do ujścia mitralnego), to w podczas rozkurczu lewej komory ciśnienie w lewym przedsionku jest ściśle powiązane z ciśnieniem w lewej komorze. Można w takim wypadku przyjąć, że podwyższone ciśnienie napełniania lewej komory przekłada się na podwyższone ciśnienie w lewym przedsionku, a ciśnienie w lewym przedsionku i w krążeniu płucnym odzwierciedla ciśnienie napełniania lewej komory [2].

Celem echokardiograficznej rozkurczowej próby wysiłkowej jest wykrycie upośledzenia rezerwy rozkurczowej lewej komory, która doprowadza do wzrostu ciśnienia napełniania lewej komory podczas wysiłku. Większość chorych z niewydolnością serca odczuwa objawy właśnie podczas wysiłku, a czynnościowe zaburzenia funkcji rozkurczowej moga je tłumaczyć. W takich wypadkach to właśnie wzrost ciśnienia napełniania lewej komory przekłada się na wzrost ciśnienia w lewym przedsionku i w krążeniu płucnym, co wiąże się z dusznością podczas aktywności fizycznej i z gorszą tolerancją wysiłku. Z tego powodu ocena ciśnienia napełniania lewej komory zyskuje coraz większe znaczenie diagnostyczne przy rozpoznawaniu niewydolności serca, 
szczególnie u chorych z zachowaną frakcją wyrzutową lewej komory. Echokardiografia umożliwia nieinwazyjną ocenę tych ciśnień [3].

\section{Ocena funkcji rozkurczowej lewej komory w spoczynkowym badaniu echokardiograficznym}

W 2016 roku ukazał się konsensus dotyczący oceny funkcji rozkurczowej Amerykańskiego Towarzystwa Echokardiograficznego (ASE, American Society of Echocardiography) oraz Europejskiej Asocjacji Obrazowania Sercowo-Naczyniowego (EACVI, European Association of Cardiovascular Imaging). Można w nim znaleźć parametry echokardiograficzne, które należy ocenić, aby ustalić obecność oraz stopień zaawansowania dysfunkcji rozkurczowej lewej komory. Warto podkreślić, że określenie funkcji rozkurczowej w badaniu spoczynkowym jest nieodłączną częścią rutynowego badania echokardiograficznego, szczególnie u chorego z dusznością i podejrzeniem niewydolności serca [4]. W wytycznych dotyczących niewydolności serca, opublikowanych w 2016 roku, nieprawidłowa funkcja rozkurczowa jest jednym z ważnych parametrów podczas ustalania rozpoznania niewydolności serca u osób z frakcją wyrzutową lewej komory co najmniej 40\% [5].

W wytycznych dotyczący oceny funkcji rozkurczowej wymieniono 18 parametrów, które są przydatne w ocenie funkcji rozkurczowej lewej komory. Mnogość tych parametrów świadczy o braku jednego idealnego parametru oceniającego dysfunkcję rozkurczową lewej komory, a co za tym idzie - o trudnościach w jej rozpoznaniu i ocenie stopnia zaawansowania. Mimo różnorodności dostępnych parametrów i trudności diagnostycznych autorzy wytypowali kilka z nich, które podlegają obowiązkowej ocenie w badaniu spoczynkowym.

Pierwszym krokiem w określeniu funkcji rozkurczowej lewej komory jest ocena morfologiczna serca oraz ocena funkcji skurczowej mięśnia lewej komory. W ocenie morfologicznej serca ważnymi wskazówkami przemawiającymi za możliwością dysfunkcji rozkurczowej są obecność pogrubienia miokardium oraz powiększenie lewego przedsionka. W ocenie funkcji skurczowej lewej komory najistotniejszym parametrem jest frakcja wyrzutowa mierzona metodą Simpsona. Za prawidłową uznaje się wartość frakcji wyrzutowej lewej komory o wartości co najmniej 50\%. W wytycznych zamieszczono osobne schematy postępowania dla osób z morfologicznie prawidłowym sercem i prawidłową frakcją wyrzutową lewej komory oraz dla tych, u których stwierdza się obniżoną frakcję wyrzutową lewej komory (<50\%) lub z chorobą miokardium z zachowaną frakcją wyrzutową lewej komory, po uwzględnieniu danych klinicznych i dotyczących budowy serca.

W pierwszej grupie chorych należy najpierw wykryć obecność zaburzeń funkcji rozkurczowej, a następnie ocenić ich nasilenie. Autorzy wytycznych wychodzą z założenia, że u osób z nieprawidłową frakcją wyrzutową lewej komory czy nieprawidłową budową mięśnia lewej komory zawsze współistnieją zaburzenia funkcji rozkurczowej, a ocena echokardiograficzna powinna być nakierowana na wykrycie podwyższonego ciśnienia w lewym przedsionku.

Na rycinie 1 zaprezentowano ogólny schemat oceny funkcji rozkurczowej lewej komory, należy jednak pamiętać, że w niektórych patologiach część z tych parametrów jest niemożliwa do pomiaru lub bezużyteczna, ponieważ ich nieprawidłowa wartość wynika z innych patologii, a nie świadczy o zaburzeniach funkcji rozkurczowej. W wytycznych z 2016 roku szczegółowo omówiono odmienności w ocenie funkcji rozkurczowej w wybranych sytuacjach klinicznych, takich jak kardiomiopatia przerostowa, istotna niedomykalność mitralna czy migotanie przedsionków.

\section{Ocena obecności zaburzeń}

funkcji rozkurczowej lewej komory

Aby ocenić obecność zaburzeń funkcji rozkurczowej lewej komory, bierze się pod uwage cztery grupy parametrów (ryc. 2):

- parametry związane z napełnianiem lewej komory, reprezentowanym przez stosunek prędkości wczesnorozkurczowej fali napływu mitralnego (fala E), oraz z uśrednioną wartością wczesnorozkurczowych prędkości bocznej i przyśrodkowej części pierścienia mitralnego (e');

- parametry związane z funkcją miokardium reprezentowane przez wartości e' bocznej i przyśrodkowej części pierścienia mitralnego osobno (e' lat i e' med);

- parametry związane z wtórną przebudową mięśnia sercowego reprezentowane przez indeksowaną na powierzchnię ciała objętość lewego przedsionka (LAVi, left atrial volume index);

- parametry związane z następstwami hemodynamicznymi dla krążenia płucnego i prawych jam serca reprezentowane przez maksymalną prędkość fali niedomykalności trójdzielnej (TRV, tricuspid regurgitation velocity).

W tabeli 1 przedstawiono punkty odcięcia dla stwierdzenia nieprawidłowych wartości wymienionych parametrów. W przypadku braku technicznych możliwości pomiaru wartości e' w obu częściach pierścienia mitralnego punkt odcięcia dla parametru E/e' lat wynosi powyżej 13, a dla E/e' med powyżej 15. W wytycznych dotyczących niewydolności serca z 2016 roku autorzy proponują nieco niższy punkt odcięcia dla nieprawidłowej wartości E/e’ na poziomie co najmniej 13 [5]. Dodatkowo podano tam również nieprawidłową wartość dla uśrednionej e', która wynosi poniżej $9 \mathrm{~cm} / \mathrm{s}$.

Warto zwrócić uwagę, że do wykrywania zaburzeń funkcji rozkurczowej nowe wytyczne nie zalecają posługiwania się stosunkiem fal E i A, natomiast nadal - jak o tym mowa 


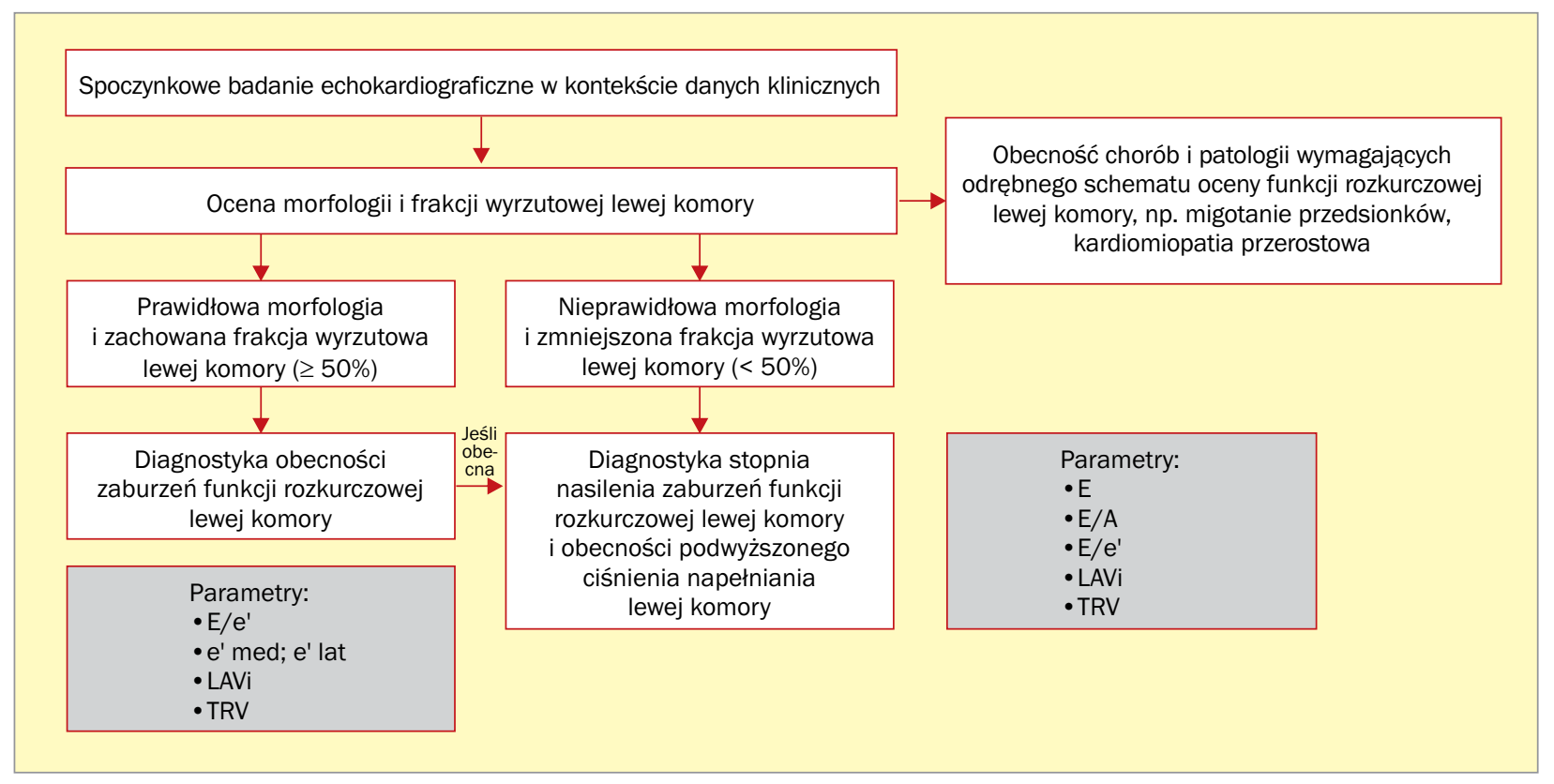

Rycina 1. Schemat oceny funkcji rozkurczowej w spoczynkowych badaniu echokardiograficznym; A - prędkości późnorozkurczowej fali napełniania lewej komory spowodowanej skurczem przedsionka; E - prędkość wczesnorozkurczowa fali napływu mitralnego; e' - uśredniona wartość wczesnorozkurczowych prędkości bocznej i przyśrodkowej części pierścienia mitralnego; e’ med - wartość wczesnorozkurczowej prędkości przyśrodkowej części pierścienia mitralnego wyrażona w centymetrach na sekundę; e' lat - wartość wczesnorozkurczowej prędkości bocznej części pierścienia mitralnego wyrażona w centymetrach na sekundę; LAVi (left atrial volume index) - indeksowana na pole powierzchni ciała objętość lewego przedsionka; TRV (tricuspid regurgitation velocity) - maksymalna prędkość fali niedomykalności trójdzielnej

Serce zdrowe

- prawidłowe parametry funkcji rozkurczowej
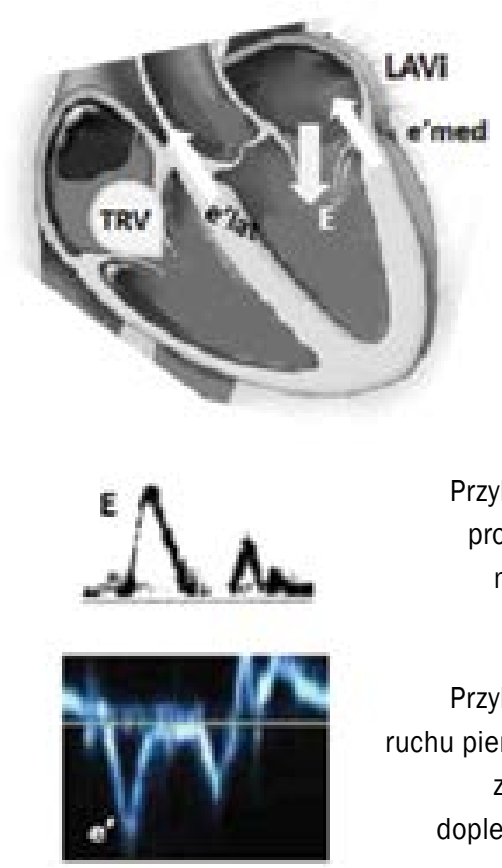

Serce z pogrubieniem ścian lewej komory

- przykład zaburzeń funkcji rozkurczowej
Przykładowy zapis

profilu napływu

mitralnego

Przykładowy zapis

ruchu pierścienia mitralnego

za pomocą

doplera tkankowego
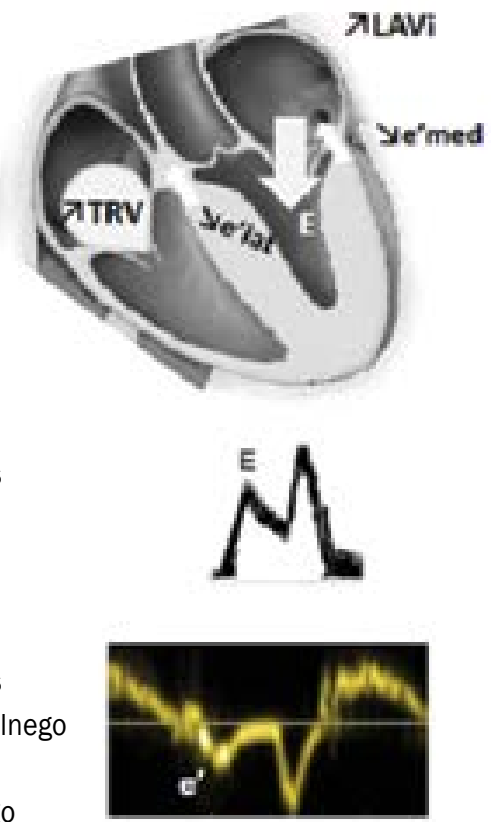

Rycina 2. Zmiany w parametrach służących wykryciu zaburzeń funkcji rozkurczowej na przykładzie chorego z pogrubieniem ścian lewej komory; E - prędkość wczesnorozkurczowa fali napływu mitralnego; e' - wartość wczesnorozkurczowych prędkości bocznej lub przyśrodkowej części pierścienia mitralnego; e’ med - wartość wczesnorozkurczowej prędkości przyśrodkowej części pierścienia mitralnego; e' lat - wartość wczesnorozkurczowej prędkości bocznej części pierścienia mitralnego; LAVi (left atrial volume index) - indeksowana na pole powierzchni ciała objętość lewego przedsionka; TRV (tricuspid regurgitation velocity) - maksymalna prędkość fali niedomykalności trójdzielnej 
Tabela 1. Punkty odcięcia dla nieprawidłowych wartości parametrów wykorzystywanych podczas oceny obecności zaburzeń funkcji rozkurczowej lewej komory

\begin{tabular}{lcc}
\hline Znaczenie parametru & Parametr & $\begin{array}{c}\text { Wartości mogące wskazywać } \\
\text { na zaburzenia funkcji rozkurczowej }\end{array}$ \\
\hline Ciśnienie napełniania lewej komory & E/e' & $>14$ \\
Funkcja miokardium (wystarczy & e' lat $^{\prime}$ & $<10 \mathrm{~cm} / \mathrm{s}$ \\
spełnienie jednego z nich) & e' $^{\prime}$ ed & $<7 \mathrm{~cm} / \mathrm{s}$ \\
Przebudowa wtórna & LAVi & $>34 \mathrm{ml} / \mathrm{m}^{2}$ \\
Wpływ hemodynamiczny na krążenia płucne & TRV & $>2,8 \mathrm{~m} / \mathrm{s}$
\end{tabular}

E - prędkość wczesnorozkurczowa fali napływu mitralnego; e' - uśredniona wartość wczesnorozkurczowych prędkości bocznej i przyśrodkowej części pierścienia mitralnego; e’ med - wartość wczesnorozkurczowej prędkości przyśrodkowej części pierścienia mitralnego; e' lat - wartość wczesnorozkurczowej prędkości bocznej części pierścienia mitralnego; LAVi (left atrial volume index) - indeksowana na pole powierzchni ciała objętość lewego przedsionka; TRV (tricuspid regurgitation velocity) - maksymalna prędkość fali niedomykalności trójdzielnej

w dalszej części artykułu - jest to kluczowy parametr przy stopniowaniu nasilenia dysfunkcji rozkurczowej.

Następnie należy ocenić, ile z wymienionych grup parametrów spełnia badana osoba. Jeśli nie spełnia żadnego lub spełnia tylko jeden z parametrów, wówczas należy uznać, że funkcja rozkurczowa jest prawidłowa. Jeśli dwa parametry przekroczyły punkty odcięcia dla wartości prawidłowych, to na podstawie tego badania nie da się rozstrzygnąć obecności dysfunkcji rozkurczowej. Natomiast jeśli u chorego występują 3 lub 4 nieprawidłowości, stwierdza się nieprawidłową funkcję rozkurczową i należy przejść do oceny stopnia jej nasilenia.

\section{Ocena stopnia nasilenia zaburzeń funkcji rozkurczowej lewej komory}

Celem oceny nasilenia zaburzeń funkcji rozkurczowej lewej komory jest w pierwszej kolejności ocena obecności podwyższonych ciśnień w lewym przedsionku. Stopień nasilenia dysfunkcji rozkurczowej określa się u wszystkich:

- z nieprawidłową funkcją rozkurczową (rozpoznaną według kryteriów opisanych wcześniej);

- nieprawidłową frakcją wyrzutową lewej komory (< 50\%);

- nieprawidłowym miokardium (np. pogrubienie) z zachowaną frakcją wyrzutową lewej komory ( $\geq 50 \%$ ).

$\mathrm{Na}$ początku ocenia się dwa parametry napływu mitralnego: wspomnianą już falę E, czyli prędkość wczesnorozkurczowej fali napływu mitralnego, oraz jej stosunek do prędkości późnorozkurczowej fali napełniania lewej komory spowodowanej skurczem przedsionka (E/A).

Jeśli stosunek $E / A$ wynosi nie więcej niż 0,8 oraz jeśli prędkość fali E wynosi nie więcej niż $50 \mathrm{~cm} / \mathrm{s}$, wówczas należy przyjąć, że w spoczynku ciśnienie krwi w lewej komorze i lewym przedsionku nie jest podwyższone i rozpoznaje się I stopnień zaburzeń funkcji rozkurczowej. Jeśli stosunek E/A wynosi co najmniej 2, to stwierdza się III stopień dysfunkcji rozkurczowej mięśnia lewej komory oraz obecność podwyższonych ciśnień w lewym przedsionku.

Największym wyzwaniem diagnostycznym są chorzy, u których stosunek fal E/A wynosi nie więcej niż 0,8 przy jednoczesnej prędkości fali E powyżej $50 \mathrm{~cm} / \mathrm{s}$ lub u których stosunek E/A wynosi 0,8-2. U tych pacjentów analizuje się dodatkowe parametry: stosunek E/e' (uśrednione), TRV oraz indeksowaną objętość lewego przedsionka. Należy posługiwać się tymi sami punktami, co przy określaniu obecność zaburzeń funkcji rozkurczowej, czyli dla stosunku E/e' powyżej 14, dla TRV więcej niż 2,8 m/s, a dla LAVi powyżej $34 \mathrm{ml} / \mathrm{m}^{2}$. Jeśli co najmniej dwa te kryteria są spełnione, to rozpoznaje się II stopnień zaburzeń funkcji rozkurczowej oraz stwierdza obecność podwyższonego ciśnienia w lewym przedsionku. Jeśli występuje tylko jedno kryterium lub wyniki wszystkich trzech parametrów są poniżej punktów odcięcia, wówczas stwierdza się I stopień dysfunkcji rozkurczowej bez współistnienia podwyższonego ciśnienia w lewym przedsionku (tab. 2) [4].

\section{Wskazania do echokardiograficznej rozkurczowej próby wysiłkowej}

Rozkurczową próbę wysiłkową należy wykonać u osób z I stopieniem zaburzeń funkcji rozkurczowej, bez podwyższonych ciśnień napełniania lewej komory w spoczynku, jeśli występują objawy sugerujące niewydolność serca, zwłaszcza duszność wysiłkowa, w celu stwierdzenia, czy odczuwane przez chorego objawy wynikają z upośledzenia rezerwy rozkurczowej [4]. Wytyczne dotyczące diagnostyki niewydolności serca wskazują szersze wskazania do wykonania echokardiograficznej rozkurczowej próby wysiłkowej. W tym dokumencie eksperci sugerują wykonanie rozkurczowej próby wysiłkowej u wszystkich chorych z podejrzeniem niewydolności serca z zachowaną frakcją wyrzutową lewej komory, u których inne badania, takie jak spoczynkowe badanie echokardiograficzne czy pomiar stężenia peptydów natriuretycznych, nie pozwoliły na potwierdzenie takiego rozpoznania, a którzy odczuwają duszność, szczególnie wysiłkową. Należy pamiętać o czynnikach ryzyka rozwoju niewydolności serca z zachowaną frakcją wyrzutową lewej komory, takich jak wiek, nadciśnienie tętnicze, cukrzyca, siedzący tryb życia czy nadwaga i otyłość [6]. 
Tabela 2. Kryteria rozpoznania różnych stopni dysfunkcji rozkurczowej mięśnia lewej komory

\begin{tabular}{|c|c|c|}
\hline $\begin{array}{l}\text { Stopień dysfunkcji } \\
\text { rozkurczowej }\end{array}$ & Kryteria & $\begin{array}{l}\text { Podwyższenie ciśnienia w lewym } \\
\text { przedsionku w spoczynku }\end{array}$ \\
\hline \multirow[t]{3}{*}{ |* } & $E / A \leq 0,8$ i prędkość fali $E \leq 50 \mathrm{~cm} / \mathrm{s}$ & \multirow[t]{3}{*}{ Nieobecne } \\
\hline & $\begin{array}{l}\text { E/A } \leq 0,8 \text { i prędkość fali } E>50 \mathrm{~cm} / \mathrm{s} \text { oraz brak dwóch lub wszystkich dodat- } \\
\text { kowych kryteriów (tj. E/e' }>14 ; \mathrm{TRV}>2,8 \mathrm{~m} / \mathrm{s} ; \mathrm{LAVi}>34 \mathrm{ml} / \mathrm{m}^{2} \text { ) }\end{array}$ & \\
\hline & $\begin{array}{l}\text { E/A powyżej 0,8 i poniżej 2_oraz brak dwóch lub wszystkich dodatkowych } \\
\text { kryteriów (tj. E/e' > 14; TRV > 2,8 m/s; LAVi > } 34 \mathrm{ml} / \mathrm{m}^{2} \text { ) }\end{array}$ & \\
\hline \multirow[t]{2}{*}{$11 *$} & $\begin{array}{l}E / A \leq 0,8 \text { i prędkość fali } E>50 \mathrm{~cm} / \mathrm{s} \text { oraz obecność dwóch lub wszystkich } \\
\text { dodatkowych kryteriów (tj. E/e' }>14 ; \mathrm{TRV}>2,8 \mathrm{~m} / \mathrm{s} ; \mathrm{LAVi}>34 \mathrm{ml} / \mathrm{m}^{2} \text { ) }\end{array}$ & \multirow[t]{2}{*}{ Obecne } \\
\hline & $\begin{array}{l}\text { E/A powyżej 0,8 i poniżej 2_oraz obecność dwóch lub wszystkich dodatko- } \\
\text { wych kryteriów (tj. E/e' > 14; TRV > 2,8 m/s; LAVi > } 34 \mathrm{ml} / \mathrm{m}^{2} \text { ) }\end{array}$ & \\
\hline III & $E / A \geq 2$ & Obecne \\
\hline
\end{tabular}

Nie powinno się wykonywać w celu diagnostycznym echokardiograficznej rozkurczowej próby wysiłkowej u chorych, u których badanie spoczynkowe pozwala na stwierdzenie podwyższonych ciśnień w lewym przedsionku, czyli w II i III stopniu dysfunkcji rozkurczowej. Być może taka próba mogłaby mieć znaczenie prognostyczne, wymaga to jednak dalszych badań i prospektywnej oceny.

Głównym celem wykonywania echokardiograficznej rozkurczowej próby wysiłkowej jest stwierdzenie rozwoju podwyższonego ciśnienia napełniania lewej komory w trakcie wysiłku u pacjentów z prawidłowym ciśnieniem napełniania lewej komory, a co za tym idzie - prawidłowym ciśnieniem w lewym przedsionku w spoczynku. Ma to szczególne znaczenie w przypadku istnienia wysiłkowych objawów niewydolności serca. Oczywiście należy wykluczyć inne przyczyny kardiologicznie i pozakardiologiczne duszności i nietolerancji wysiłku, takie jak choroba wieńcowa, istotne wady zastawkowe, niedokrwistość czy schorzenia układu oddechowego.

\section{Wybrane aspekty techniczne echokardiograficznej rozkurczowej próby wysiłkowej}

Najczęściej rozkurczową próbę wysiłkową wykonuje się na cykloergometrze. Nie można zastąpić wysiłku fizycznego innymi metodami obciążeniowymi, takimi jak dobutamina czy szybka stymulacja serca, ponieważ użycie tych metod samo w sobie wpływa na funkcję rozkurczową.

W trakcie echokardiograficznej próby wysiłkowej, aby ocenić funkcję rozkurczową, bierze się pod uwagę napływ mitralny, prędkości miokarialne przyśrodkowej i bocznej części pierścienia mitralnego oraz prędkość szczytową fali zwrotnej przez zastawkę trójdzielną (TRV). Akwizycji obrazów należy dokonać: w spoczynku, na każdym etapie wysiłku oraz w trakcie odpoczynku. Ograniczeniem oceny funkcji rozkurczowej w wysiłku jest fuzja fali $E$ i fali A napływu mitralnego w przypadku wysokiej czynności serca, zazwyczaj już powyżej 110/min. W takim przypadku nie należy wykonywać pomiarów fali $\mathrm{E}$, natomiast można oceniać dalsze zmiany w TRV. Istnieje wiele różnych protokołów echokardiograficznej wysiłkowej próby rozkurczowej, szerzej omówiono jeden z nich [7].

Grupa EU-FP7 MEDIA po przeanalizowaniu 38 badań oceniających funkcje rozkurczową w wysiłku zaproponowała użyteczny klinicznie skrócony protokół badania na cykloergometrze (Cardiff-MEDIA protocol). Zakłada on wykonanie oceny echokardiograficznej w minimum trzech punktach czasowych: na początku badania przed rozpoczęciem wysiłku, przy pojawieniu się objawów lub osiągnięciu tętna 100-110/min oraz w trakcie odpoczynku w momencie separacji fali napływu mitralnego lub po 2 minutach. Początkowe obciążenie na cykloergometrze wynosi $15 \mathrm{~W}$, a następnie jest zwiększane o $5 \mathrm{~W}$ co minutę. Prędkość pedałowania powinna być utrzymywana na poziomie 55-65 razy/min. Protokół ten przedstawiono na rycinie 3 [6].

Alternatywą dla cykloergometru może być wykorzystanie testu wysiłkowego na bieżni. Wtedy akwizycji obrazów echokardiograficznych dokonuje się przed rozpoczęciem wysiłku oraz po jego zakończeniu, w czasie odpoczynku, po odpowiednim zwolnieniu tętna, gdy pomiar fali E staje się możliwy.

Oczywiście ocena zmian parametrów funkcji rozkurczowej w trakcie wysiłku może być częścią echokardiograficznej próby wysiłkowej ukierunkowanej na zbadanie innych parametrów, na przykład odcinkowych zaburzeń kurczliwości w przypadku podejrzenia choroby wieńcowej. 


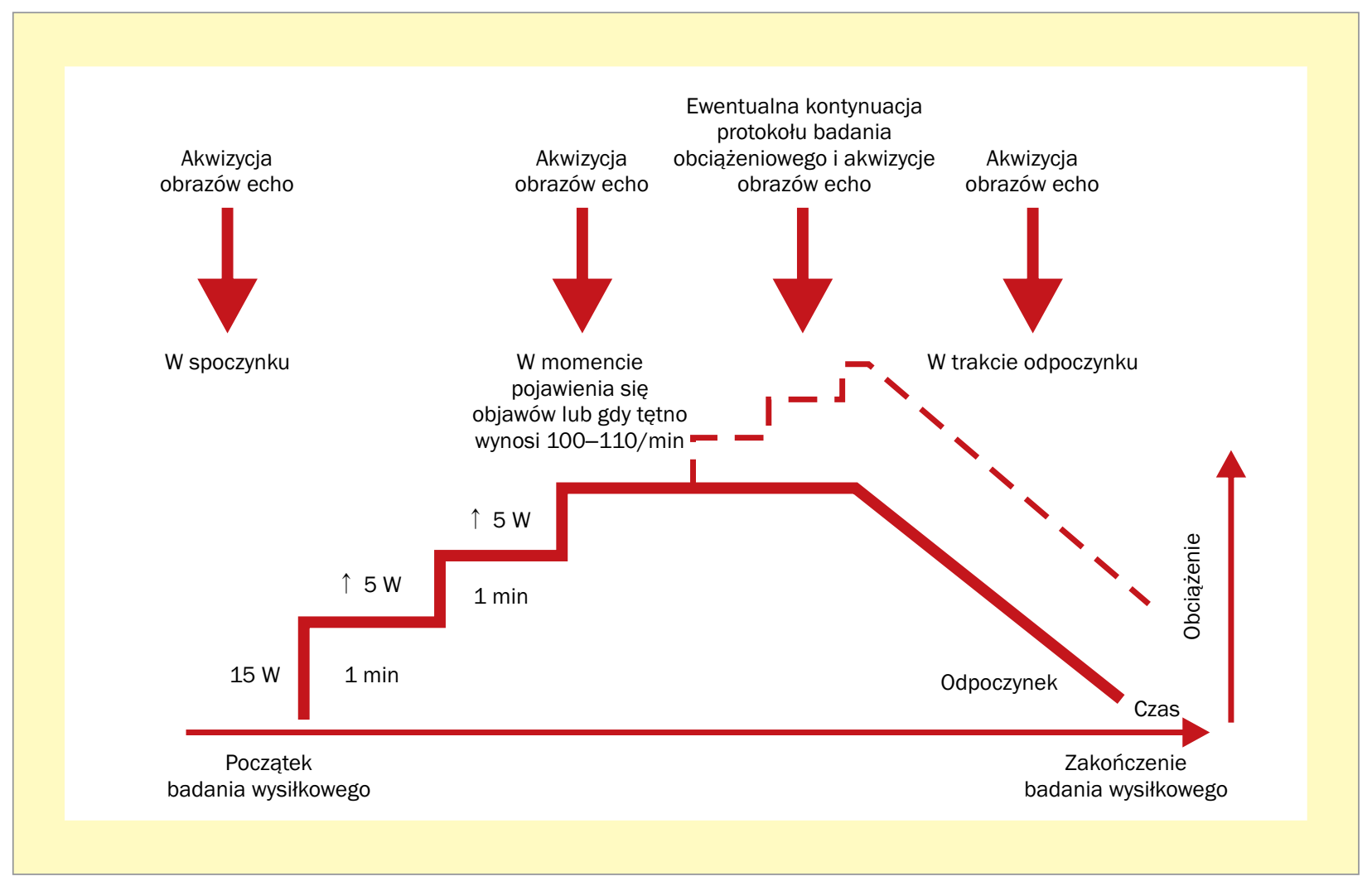

Rycina 3. Protokół echokardiograficznej rozkurczowej próby wysiłkowej Cardiff-MEDIA zaproponowany przez grupę EU-FP7 MEDIA; echo echokardiograficzny

\section{Interpretacja wyników echokardiograficznej rozkurczowej próby wysiłkowej}

Podczas oceny wyników echokardiograficznej rozkurczowej próby wysiłkowej przede wszystkim określa się stosunek E/e' oraz TRV, czyli te parametry, które obrazują ciśnienie napełniania lewej komory i jego wpływ na krążenie płucne, w przypadku wystąpienia objawów lub na szczycie wysiłku oraz w trakcie odpoczynku.

Zgodnie z wytycznymi ASE oraz EACVI z 2016 roku za wynik nieprawidłowy, wskazujący na wysiłkowe upośledzenie rezerwy rozkurczowej uznaje się wzrost stosunku fali E do uśrednionej wartości fali e' powyżej 14 lub wzrost stosunku fali E do wartości fali e' med więcej niż 15 ze wzrostem TRV powyżej 2,8 m/s, jeśli w spoczynku stwierdzono obniżone prędkości miokardialne (wartość fali e' med $<7 \mathrm{~cm} / \mathrm{s}$ lub fali e' lat < $10 \mathrm{~cm} / \mathrm{s}$ ). Jako wynik prawidłowy uważa się uzyskanie wartości E/e' (uśrednionego lub przyśrodkowego) poniżej 10 ze szczytową prędkością fali zwrotnej przez zastawkę trójdzielną mniejszą niż $2,8 \mathrm{~m} / \mathrm{s}$ podczas wysiłku. W pozostałych przypadkach wynik testu jest niediagnostyczny. W takich wypadkach autorzy wytycznych sugeruja ewentualne wykonanie badań inwazyjnych w celu oceny ciśnienia napełniania lewej komory. Podsumowanie interpretacji echokardiograficznej rozkurczowej próby wysiłkowej przedstawiono w tabeli 3.
Warto podkreślić, że przytoczona interpretacja wyników oraz zaproponowane punkty odcięcia nie były powszechnie walidowane. W niektórych badaniach wykazano, że stosunek E/e' już powyżej 13 wiąże się z gorszą tolerancją wysiłku, a także ma wysoką wartość prognostyczną w wykrywaniu choroby niedokrwiennej serca $[4,8]$. Być może dlatego w wytycznych dotyczących niewydolności serca za nieprawidłowy uznaje się stosunek E/e’ na poziomie co najmniej 13 [5].

\section{Podsumowanie}

Ocena funkcji rozkurczowej mięśnia lewej komory w spoczynku stanowi integralną część badania echokardiograficznego. W przypadku gdy w badaniu spoczynkowym stwierdza się I stopień dysfunkcji rozkurczowej lub gdy istnieje duże kliniczne podejrzenie niewydolności serca, a dotychczasowe badania nie pozwalają rozstrzygnąć o ostatecznym rozpoznaniu, warto skierować chorego na echokardiograficzną rozkurczową próbę wysiłkową. Jest to badanie zazwyczaj wykonywane na cykloergometrze, rzadziej z wykorzystaniem bieżni. Istnieje wiele możliwych protokołów badania. Jednym z łatwiejszych i bardziej użytecznych jest omówiony protokół Cardiff-MEDIA z wykonaniem przynajmniej 3 akwizycji obrazów echokardiograficznych. Podczas wysiłku ocenia się przede wszystkim stosunek E/e' świadczący o ciśnieniu w lewej 
Tabela 3. Sposób interpretacji wyników echokardiograficznej rozkurczowej próby wysiłkowej proponowany przez Amerykańskie Towarzystwo Echokardiograficzne oraz Europejską Asocjację Obrazowania Sercowo-Naczyniowego z 2016 roku

$\begin{array}{lccc}\text { Parametr } & \begin{array}{c}\text { Wynik prawidłowy } \\ \text { (oba warunki muszą } \\ \text { być spełnione łącznie) }\end{array} & \begin{array}{c}\text { Wynik niediagnostyczny } \\ \text { Wynik nieprawidłowy* } \\ \text { (oba warunki muszą } \\ \text { być spełnione łącznie) }\end{array} & 10-14(15) \\ \text { E/e' (lub E/e' med) } & <10(10) & \text { Dowolna } & >14(15) \\ \text { TRV }[\mathrm{m} / \mathrm{s}] & <2,8 & >2,8\end{array}$

*Dodatkowo w badaniu spoczynkowym prędkość e' med < $7 \mathrm{~cm} / \mathrm{s}$ lub jeśli zarejestrowano tylko e' lat to musi ono być < $10 \mathrm{~cm} / \mathrm{s}$; $E$ - prędkość wczesnorozkurczowa fali napływu mitralnego; e' - uśredniona wartość wczesnorozkurczowych prędkości bocznej i przyśrodkowej części pierścienia mitralnego; e' med - wartość wczesnorozkurczowej prędkości przyśrodkowej części pierścienia mitralnego (używana przy interpretacji w przypadku braku możliwości pomiaru prędkości obu części pierścienia mitralnego); TRV (tricuspid regurgitation velocity) - maksymalna prędkość fali niedomykalności trójdzielnej

komorze w trakcie wysiłku oraz maksymalną prędkość fali zwrotnej przez zastawkę trójdzielną wskazującą pośrednio na wpływ wzrostu tego ciśnienia na ciśnienia w krążeniu płucnym. Nieprawidłowe wartości obu tych parametrów w trakcie wysiłku przy obniżonych prędkościach miokardialnych w spoczynku świadczą o dysfunkcji rozkurczowej z podwyższonymi wartościami ciśnienia napełniania lewej komory i ciśnienia w lewym przedsionku w trakcie wysiłku.

\section{Abstract}

Diastolic dysfunction can lead to heart failure symptoms if it causes elevated left atrial pressure. Diastolic function changes dynamically for example during physical exercise. That is why echocardiography at rest may not detect signs of left atrial pressure elevation. In this article, we present an outline of diastolic function assessment at rest, and indications for a diastolic stress test, its protocols and interpretation.

Key words: echocardiography, diastole, steress test, diastolic dysfunction, heart failure

Folia Cardiologica 2018; 13, 6: 588-594

\section{Piśmiennictwo}

1. Lewartowski B. Patofizjologia rozkurczowej niewydolności serca. Kardiol Pol. 2008; 66: 1096-1101.

2. Blume GG, Mcleod CJ, Barnes ME, et al. Left atrial function: physiology, assessment, and clinical implications. Eur J Echocardiogr. 2011; 12(6): 421-430, doi: 10.1093/ejechocard/jeq175, indexed in Pubmed: 21565866.

3. Andersen OS, Smiseth OA, Dokainish H, et al. Estimating Left Ventricular Filling Pressure by Echocardiography. J Am Coll Cardiol. 2017; 69(15): 1937-1948, doi: 10.1016/j.jacc.2017.01.058, indexed in Pubmed: 28408024.

4. Nagueh SF, Smiseth OA, Appleton CP, et al. Recommendations for the evaluation of left ventricular diastolic function by echocardiography: an update from the American Society of Echocardiography and the European Association of Cardiovascular Imaging. J Am Soc Echocardiogr. 2016; 29(4): 277-314, doi: 10.1016/j.echo.2016.01.011, indexed in Pubmed: 27037982.

5. Ponikowski P, Voors AA, Anker SD, et al. Authors/Task Force Members, Document Reviewers, ESC Scientific Document Group. 2016 ESC Guidelines for the diagnosis and treatment of acute and chro- nic heart failure: The Task Force for the diagnosis and treatment of acute and chronic heart failure of the European Society of Cardiology (ESC)Developed with the special contribution of the Heart Failure Association (HFA) of the ESC. Eur Heart J. 2016; 37(27): 2129-2200, doi: 10.1093/eurheartj/ehw128, indexed in Pubmed: 27206819.

6. Erdei T, Smiseth OA, Marino P, et al. A systematic review of diastolic stress tests in heart failure with preserved ejection fraction, with proposals from the EU-FP7 MEDIA study group. Eur J Heart Fail. 2014; 16(12): 1345-1361, doi: 10.1002/ejhf.184, indexed in Pubmed: 25393338.

7. Takagi T. Diastolic stress echocardiography. J Echocardiogr. 2017; 15(3): 99-109, doi: 10.1007/s12574-017-0335-7, indexed in Pubmed: 28271289.

8. Burgess MI, Jenkins C, Sharman JE, et al. Diastolic stress echocardiography: hemodynamic validation and clinical significance of estimation of ventricular filling pressure with exercise. J Am Coll Cardiol. 2006; 47(9): 1891-1900, doi: 10.1016/j.jacc.2006.02.042, indexed in Pubmed: 16682317. 